\title{
PERILAKU DEBITUR DALAM MENENTUKAN PEMBIAYAAN SYARIAH (STUDI PADA BPRS DI WILAYAH TANGERANG DAN BEKASI)
}

\author{
Hasnil Hasyim \\ DPP Ikatan Ahli Ekonomi Islam
}

\begin{abstract}
Behavior of Debtor in Determining The Sharia Finance: Study at Islamic Rural Banking in Tangerang and Bekasi. The aim of this study is to measure the preferences of debtor in shariah financing. Analysis method that used in this research is logit regression. Independent variables of this research are age, type of business, busines turnover, time, location, and value of financing. From the research it can be concluded that the debtor is engaged in the trade sektor, which has a turnover of approximately 20 - 50 millior/month, businesses located in the market, runs its business more than 2 years, borrowers who become customers of the bank for one year and the value of financing 10-25 million given to banks is more dominant in determining murabahah financing.
\end{abstract}

Keyword : Debtor behavior, logit regression, shariah financing

\begin{abstract}
Abstrak. Perilaku Debitur Dalam Menentukan Pembiayaan Syariah: Studi Pada BRPS di Wilayah Tangerang and Bekasi. Tujuan dari studi dalam mengukur preferensi debitur dalam pembiayaan syariah. Metode analisis yang dipergunakan dalam penelitian ini adalah regresi logi. Variabel independen dalam penelitian ini ialah usia, jenis usaha, omzet perusahaan, jangka waktu, lokasi, dan nilai pembiayaan. Berdasarkan penelitian ini dapat disimpulkan bahwa debitur yang terlibat pada sektor perdagangan, berlokasi di pasar dan memiliki omset usaha sebesar 20 - 50 juta per bulan, menjalankan usaha lebih dari dua tahun, telah menjadi nasabah bank selama satu tahun, dan nilai pembiayaan sebesar 10 - 25 juta merupakan faktor yang lebih dominan dalam memilih pembiayaan murabahah.
\end{abstract}

Kata Kunci: perilaku debitur, regresi logit, pembiayaan syariah 


\section{PENDAHULUAN}

Bank pada hakikatnya adalah lembaga keuangan intermediasi antara penabung dan investor. Tabungan hanya akan berguna bila diinvestasikan, sedangkan para penabung tidak dapat diharapkan untuk sanggup melakukannya sendiri dengan terampil dan sukses. Nasabah mau menyimpan dananya di bank karena percaya bahwa bank dapat memilih alternatif invesatsi yang menarik. Proses pemilihan investasi harus dilakukan dengan seksama karena kesalahan dalam pemilihan bentuk invesatsi akan membawa akibat bank tidak bisa memenuhi kewajibannya kepada para nasabah.

Loan to deposit ratio (LDR) merupakan rasio investasi portofolio suatu bank pada investasi sektor riil yang diharapkan memiliki return yang cukup tinggi. Dampak negatif dari LDR adalah resiko kredit. Hal ini akan muncul jika bank tidak bisa memperoleh kembali cicilan pokok atau bunga dari pinjaman yang diberikannya atas investasi yang dilakukan.

Jenis risiko lainnya yang sering dihadapi oleh perbankan adalah risiko likuiditas. Pemicu utama kebangkrutan yang dialami oleh bank, besar atau kecil bukanlah karena kerugian yang dideritanya melainkan lebih kepada ketidakmampuan bank memenuhi likuiditasnya. Likuiditas secara luas dapat didefinisikan sebagai kemampuan untuk memenuhi kebutuhan dana (cashflow) dengan segera dan dengan biaya yang sesuai. Likuiditas penting bagi bank untuk menjalankan transaksi bisnis sehari-hari, mengatasi kebutuhan dana yang mendesak, memuaskan permintaan nasabah terhadap para peminjam dan memberikan fleksibilitas dalam meraih kesempatan invesatsi yang lebih menarik dan menguntungkan.

Adanya perbankan syariah saat ini yang diikuti dengan tingginya loan to deposit ratio secara teori akan meningkatnya risiko kredit pada pada perbankan syariah tersebut,untuk menekan risiko kredit maka perlu dilakukan kajian mengenai prilaku debitur dan faktor-faktor yang mempengaruhi debitur dalam menentukan pembiayaan syariah.

\section{METODE}

Penelitian ini menggunakan metode penelitian kualitatif, dari hasil datadata yang diperoleh dari bank yang berkaitan dengan debitur (data sekunder) 
kemudian dikuantitatifkan yaitu ditransformasikan atau diolah dalam pendekatan ekonometri yang dikenal dengan model logit. Pendekatan ekonometri dengan menggunakan model logit merupakan alat untuk menganalisis data-data kuantitatif dengan bantuan komputer setelah terlebih dahulu dilakukan pengkodean, verifikasi dan pengeditan sehingga keakuratan data lebih mudah dianalisis.

Untuk variabel debitur dalam menentukan pembiayaan syariah, maka penulis menentukan 7 variabel yaitu (usia debitur, jenis usaha, omset penjualan, lamanya menjalankan usaha, lokasi usaha, lamanya debitur menjadi nasabah dan nilai pembiayaan). Model persamaan logit yang diajukan dalam penelitian ini ialah:

$$
Y=\beta_{0}+\beta_{1} X_{1}+\beta_{2} X_{2}+\beta_{3} X_{3}+\beta_{4} X_{4}+\beta_{5} X_{5}+\beta_{6} X_{6}+\beta_{7} X_{7}+\varepsilon
$$

Dimana ,

$\mathrm{Y}=$ Preferensi debitur memilih produk mudharabah/lainnya

Nilai 1 : Bila pilihan debitur mudharabah/musyarakah.

Nilai 0 : Bila pilihan debitur murabahah/jual beli.

$\mathrm{X}_{1}=\mathrm{usia}$

$\mathrm{X}_{2}=$ Jenis usaha

$\mathrm{X}_{3}=$ omset penjualan/bulan

$\mathrm{X}_{4}=$ lamanya menjalankan usaha

$\mathrm{X}_{5}=$ lokasi usaha

$\mathrm{X}_{6}=$ lamanya debitur menjadi nasabah

$\mathrm{X}_{7}=$ nilai pembiayaan

Sebelum melakukan pengolahan data dengan menggunakan metode regresi logistik, maka pengujian variable-variabel dengan analisis faktor harus dilakukan. Pengujian analisis faktor merupakan suatu teknik statistik yang digunaan untuk mengekstrak (mereduksi) sejumlah variabel atau unit observasi yang diteliti dapat digabungkan ke dalam faktor (komponen utama) dasar yang jumlahnya lebih kecil dari sekumpulan variabel-variabel asal, tetapi masih memiliki informasi yang mendekati nilai informasi yang dibutuhkan.

Standar dalam penghitungan pengujian data untuk faktor analisis, ialah: pertama, sebagian besar ( $>50 \%$ ) nilai matrik korelasi mempunyai nilai lebih 
besar dari 0,3. Kedua, nilai Kaiser-Meyen-Olkin (KMO) harus lebih besar dari 0,5. Ketiga, milai partial korelasi untuk setiap variable lebih besar dari 0,5, jika nilai Partial Korelasi suatu variable $<0,5$ maka variable tersebut tidak digunakan dalam factor analisis. Keempat, nilai Bartlett test of sphericity besar pada tingkat signifikan kecil. Kelima, Jika syarat 1,2 dan 4 terpenuhi maka data yang digunakan dapat dilanjutkan untuk dihitung dengan menggunakan metode principal komponen.

Bentuk model regresi logistic menurut Nachrowi (2002), adalah sebagai berikut:

$E\left(Y=\frac{1}{x_{i}}\right)=\pi\left(x_{i}\right)=\frac{\operatorname{Exp}\left(\beta_{0}+\beta_{1} X_{1}+\beta_{2} X_{2}+\cdots+\beta_{k} X_{K}\right.}{1+\exp \left(\beta_{0}+\beta_{1} X_{1}+\beta_{2} X_{2}+\cdots+\beta_{k} X_{k}\right.}$

Dimana $\mathrm{x}_{1}$ sampai dengan $\mathrm{x}_{\mathrm{k}}$ adalah peubah penjelas ke-1 sampai dengan ke-k. Untuk memperoleh fungsi yang linier $\mathrm{g}(\mathrm{x})$, model tersebut biasanya ditransformasikan menjadi bentuk tertentu yang dikenal dengan nama tranformasi logit.

Pada model regresi logistic dengan prinsip yang sama uji signifikan dilakukan terhadap fungsi logaritma likelihood, biasanya dikenal dengan uji nisbah kemungkinan (likelihood ratio test). Uji statistik yang digunakan adala G $=-2 \ln$ (likelihood tanpa peubah penjelas/likelihood dengan peubah penjelas) yang mengikuti sebaran khi-kuadrat dengan derajad bebas dimana $\mathrm{p}$ adalah jumlah peubah bebas penjelas. Uji signifikan lain yang dilakukan adalah uji wald (wald test), uji ini digunakan untuk memeriksa keberartian beta secara parsial, yaitu membandingkan dugaan beta dengan penduga ragamnya.

Interpretasi koefisien-koefisien dalam model regresi logistik dilakukan dalam bentuk odds ratio (perbandingan resiko) atau dalam adjusted probability (probabilitas terjadi).

Data yang digunakan adalah data sekunder yang berkaitan dengan prilaku debitur seperti usia, jenis usaha, omset penjualan, lamanya menjalankan usaha, lokasi usaha, lamanya berinteraksi dengan bank dan nilai pembiayaan. Adapun data-data diperoleh melalui berbagai BPRS yang berada di lokasi Ciputat, Ciledug, Tangerang dan Pondok Cabe.

Tehnik pengambilan sample dilakukan dengan cara acak sederhana (simple random sampling) dan didapat sebanyak 4 nama BPRS secara acak 
sederhana sebagai objek penelitian. Dari satu BPRS tersebut diambil 100 data yang berkaitan dengan prilaku debitur sehingga data yang diperoleh kurang lebih berjumlah 400 data debitur, kemudian data tersebut diolah.

\section{PEMBAHASAN}

Dari hasil penelitian yang dilakukan didapat nilai estimasi, uji wald dan nilai exp (B), yang kesemuanya merupakan bentul model yang didapatkan. Dari tabel tersebut dapat dilihat bahwa semua koefisien variabel bebas signifikan secara statistik pada alfa $=5 \%$, kecuali koefisien pada variabel 2 (usia), variabel 3 (jenis usaha) dan variabel 5 (lamanya menjalankan usaha).

Kembali pada substansi masalah yaitu ingin meneliti faktor-faktor apakah yang mempengaruhi debitur dalam menentukan pembiayaan syariah dan apakah usia, jenis usaha, lamanya menjalankan usaha juga sangat mempengaruhi kecenderungan dalam menentukan pembiayaan syariah tersebut. Jika salah satu dikeluarkan dalam model maka kehilangan informasi, mengingat koefisien tersebut merupakan perbandingan antara sektor jasa dan perdagangan maka tidak mudah bagi kita untuk menentukan variabel mana yang akan dibuang. Mengeluarkan sektor jasa merupakan cerminan dari usaha debitur begitu pula sektor perdagangan.

Berdasarkan hasil yang didapat, maka dapat diinterpretasikan bahwa dengan nilai intersep sebesar -0,376,yang berarti bahwa pada saat semua variable 0 yaitu usia berkode 0 ( $>50$ th), jenis usaha berkode 0 (industri), omset berkode 0 ( $>51$ juta), lamanya usaha berkode 0 ( $>5$ thn) lokasi usaha berkode 0 (ruko/kantor), lamanya menjadi nasabah 0 (> 1thn) dan nilai pembiayaan 0 (> 51 juta), maka probabilita mereka memilih pembiayaan murabahah adalah :

$$
\begin{aligned}
\operatorname{Ln}(\mathrm{p} / 1-\mathrm{p}) & =-0,376 \\
(\mathrm{p} / 1-\mathrm{p}) & =\exp -0,376 \\
\mathrm{P} & =\exp -0,376 /(1-\exp -0,376)=0,4070=40,70 \%
\end{aligned}
$$

Pada hasil penelitian diatas terlihat bahwa peluang debitur yang berusia diatas 50 tahun lebih dominan untuk memilih pembiayaan murabahah dibanding dengan debitur yang berusia dibawah 50 tahun. Pernyataan ini tidak sesuai dengan realitas yang terjadi di BPRS sehingga perlu diluruskan, 
sebaiknya dinyatakan bahwa peluang debitur yang berusia 30-50 tahun untuk memilih pembiayaan murabahah lebih dominan dibanding debitur yang berusia diatas 50 tahun. Hal ini dimungkinkan terjadi pada data yang diperoleh, maksudnya adalah pada saat debitur akan meminjam pembiayaan pada bank,maka seringkali terjadi bahwa pembiayaan tersebut ditandatangani oleh wakil peminjam yang memiliki hubungan emosional dengan pihak bank. Sedangkan yang mengelola usahanya adalah pihak ketiga seperti istrinya atau keluarganya sehingga dapat dikhawatirkan terjadi kurang validnya/signifikansi dari variabel usia pada persamaan model diatas.

Nilai koefisien slope untuk variabel jenis usaha 1 (sektor perdagangan) adalah 0,745 . Hal ini menunjukkan bahwa peluang debitur yang bergerak pada sektor perdagangan untuk memilih pembiayaan murabahah lebih tinggi. Dengan nilai exp (B) sebesar 2,106 dapat diartikan bahwa peluang debitur yang bergerak pada sektor perdagangan untuk memilih pembiayaan murabahah lebih tinggi 2,106 kali peluang jenis usaha industri. Pada hasil penelitian diatas terlihat bahwa peluang jenis usaha debitur yang bergerak pada sektor perdagangan lebih tinggi untuk memilih pembiayaan murabahah dibanding sektor lainnya seperti sektor jasa dan industri.

Nilai koefisien slope untuk omset penjualan 1 dibawah 20 juta $(<20$ juta) adalah 1,849. Hal ini menunjukkan bahwa peluang kelompok debitur yang mempunyai omset penjualan dibawah 20 juta untuk memilih pembiayaan murabahah lebih tinggi dibandingkan dengan kelompok debitur yang beromset penjualan diatas 50 juta/bulan. Dengan nilai exp (B) sebesar 6,353 dapat diartikan bahwa peluang kelompok debitur yang mempunyai omset penjualan dibawah 20 juta untuk memilih pembiayaan murabahah lebih tinggi 6,353 kali dibandingkan dengan kelompok debitur yang mempunyai omset diatas 50 juta.

Hasil penelitian diatas menunjukkan bahwa debitur yang memiliki omset penjualan/bulan sekitar 20-50 juga memiliki peluang yang lebih tinggi untuk memilih pembiayaan murabahah dibanding debitur yang memiliki omset penjualan dibawah 20 juta dan diatas 50 juta. Nilai koefisien slope untuk lamanya menjalankan usaha (1) yaitu kurang dari 2 tahun adalah -1,270. Hal ini menunjukkan bahwa peluang yang menjalankan usahanya kurang dari 2 tahun 
untuk memilih pembiayaan murabahah lebih kecil dibandingkan kelompok debitur yang menjalankan usahanya diatas 5 tahun. Dengan nilai exp (B) sebesar 0,281 dapat diartikan bahwa peluang kelompok debitur yang menjalankan usahanya kurang dari 2 tahun lebih kecil 0,281 kali dibanding kelompok debitur yang menjalan usahanya lebih dari 5 tahun.

Berdasarkan temuan di atas, kita dapat menemukan suatu fakta bahwa debitur yang akan memilih pembiayaan berbasis murabahah ialah debitur yang memiliki omset sekitar 20 - 50 juta. Hal ini dapat dimungkinkan bahwa apabila semakin besar omset penjualan dari debitur tersebut, dapat terjadi suatu kemungkinan bahwa debitur bersangkutan lebih tertarik memilih pembiayaan berbasis bagi hasil seperti mudharabah atau musyarakah.

Dari hasil penelitian diatas dapat disimpulkan bahwa debitur yang menjalankan usahanya lebih dari 5 tahun peluang untuk memilih pembiayaan murabahah lebih tinggi dibanding debitur yang menjalankan usahanya kurang dari 2 tahun. Hal ini sesuai dengan aturan main yang terdapat di BPRS yaitu minimal lamanya usaha debitur 2 tahun.

Jangka waktu menjadi salah satu hal yang turut menjadi perhatian, karena semakin lama seorang debitur telah menjalankan usahanya, maka diasumsikan usahanya sudah stabil dan akan melakukan pengembangan usaha. Debitur akan mencari sumber pembiayaan yang murah dan cepat guna pengembangan usahanya. Dari perspektif bank, semakin lama usaha debitur telah berjalan, maka usaha tersebut layak untuk diberikan pembiayaan.

Nilai koefisien slope untuk lokasi usaha 1, yaitu debitur yang menjalankan usahanya di pasar sebesar 2,918 yang berarti bahwa debitur yang menjalankan usahanya di pasar lebih tinggi untuk memilih pembiayaan murabahah dengan nilai exp (B) sebesar 18,504 menunjukkan bahwa peluang debitur yang berlokasi usaha di pasar lebih tinggi 18,504 kali dibanding debitur yang berlokasi di ruko/kantor, rumah penduduk dan di pinggir jalan.

Lamanya menjadi nasabah dan nilai pembiayaan merupakan proksi (pendekatan) kepercayaan pihak perbankan kepada nasabah dan merupakan korelasi positif dengan tingkat kepercayaan artinya adalah pada saat nasabah cukup lama berinteraksi dengan bank dan nilai pembiayaan yang diberikan 
cukup tinggi maka tingkat kepercayaan makin tinggi pula, begitu pula sebaliknya dan dapat berpengaruh langsung pada pembiayaan yang diberikan. Nilai koefisien slope untuk variable lamanya menjadi nasabah sebesar 0,845 dengan nilai exp (B) sebesar 2,329. Hal ini menunjukkan peluang kelompok nasabah yang berinteraksi dengan bank selama kurang dari 1 tahun lebih dominan untuk memilih pembiayaan murabahah sebesar 2,329 kali dibanding pada kelompok nasabah yang berinteraksi pada bank lebih dari 1 tahun. Nilai koefisien pada nilai pembiayaan 1 ( $<10$ juta) sebesar 0,909 dengan nilai exp (B) 2,482. Hal ini menunjukkan bahwa peluang kelompok debitur yang diberikan pinjaman kurang dari 10 juta lebih dominan 2,482 kali dibanding dengan kelompok debitur yang diberi pinjaman diatas 50 juta.

Hasil penelitian diatas menunjukkan bahwa debitur yang diberikan pinjaman sekitar 10-25 juta memiliki peluang lebih tinggi dibandingkan dengan debitur yang diberikan pinjaman dibawah 10 juta dan diatas 25 juta. Hal ini sesuai dengan regulasi Bank Indonesia yang ditetapkan bahwa BPRS saat ini mengenai plafond pembiayaan yang diberikan kepada nasabah disesuaikan dengan aset yang dimiliki BPRS tersebut.

Berdasarkan hasil olahan data yang telah dilakukan, diantara 7 variabel yang mempengaruhi debitur dalam menentukan pola pembiayaan syariah diantaranya usia, jenis usaha, omset penjualan, lamanya menjalankan usaha, lokasi usaha, lamanya menjadi nasabah dan nilai pembiayaan yang diberikan bank. Dari temuan ini menarik suatu benang merah, bahwa dimungkinkan adanya variabel-variabel lain yang lebih dominan dalam menentukan pembiayaan syariah.

\section{SIMPULAN}

Hasil penelitian ditujukan untuk memberikan jawaban, faktor-faktor apakah yang mempengaruhi debitur dalam menentukan pembiayaan syariah Dari hasil penelitian dapat disimpulkan bahwa debitur yang bergerak di sektor perdagangan,yang memiliki omset penjualan sekitar 20-50 juta/bulan, berlokasi usaha di pasar, yang menjalankan usahanya lebih dari 2 tahun, debitur yang menjadi nasabah bank selama 1 tahun dan nilai pembiayaan yang 
diberikan pada bank 10-25 juta adalah lebih dominan dalam menentukan pembiayaan murabahah.

Perbankan syariah dalam hal ini BPRS hendaknya lebih memperhatikan pembiayaan syariah kepada debitur yang bergerak pada sektor industri kecil dan menengah. Dari 3 jenis usaha yaitu sektor perdagangan,sektor jasa dan sektor industri kecil,dan hasil penelitian menunjukkan sektor perdagangan lebih dominan dalam pembiayaan murabahah, maka BPRS diharapkan dapat memberikan porsi yang feasible kepada sektor industri kecil dan menengah karena dampaknya lebih menyentuh pengusaha kecil yang secara langsung berdampak positif pada peningkatan perekonomian masyarakat serta mengurangi pengangguran.

Diantara 7 variabel yang mempengaruhi debitur dalam menentukan pola pembiayaan syariah diantaranya usia, jenis usaha, omset penjualan, lamanya menjalankan usaha, lokasi usaha, lamanya menjadi nasabah dan nilai pembiayaan yang diberikan bank maka dimungkinkan adanya variabel-variabel lain yang lebih dominan dalam menentukan pembiayan syariah.

\section{PUSTAKA ACUAN}

Al Arif, M.N. R. 2011. Dasar-dasar Ekonomi Islam. Surakarta: Era Intermedia Al Arif, M.N.R. 2012. Lembaga Keuangan Syariah: Kajian Teoritis Praktis. Bandung: Pustaka Setia.

Al-Umar, F \& A. Haq. 1996. Islamic Banking: Theory, Practice and Challenges. Oxford: Oxford University Press.

Antonio, M. Syafii. 2001. ,Bank syariah dari teori ke praktek. Jakarta: PT.Gema Insani Press.

Boediono \& Wayan Koster. 2008. Teori dan Aplikasi Statistika dan Probabilitas. Bandung: PT Remaja Rosdakarya.

Gujarati, D. N. 2006. Dasar-dasar Ekonometrika. Ed.Ketiga, Jilid1. Jakarta: Erlangga.

Hadi, Sutrisno. 2004. Metodologi Research. Jilid 1, Ed. Kedua. Yogyakarta: Andi Offset.

Lichtenstein, S \& P. Slovic. 2006. The Construction of Preference. New York: Cambridge University Press. 
Nachrowi, N. D. \& H. Usman. 2008. Penggunaan Teknik Ekonometri: Pendekatan Populer dan Praktis Dilengkapi Teknik Analisis dan Pengolahan Data dengan Menggunakan Paket Program SPSS. Jakarta: PT RajaGrafindo Persada.

Rochaety, Ety, dkk. 2007. Metode Penelitian Bisnis: Dengan Aplikasi SPSS. Jakarta: Mitra Wacana Media, 2007.

Trihendradi, C. 2007. Kupas Tuntas Analisis Regresi. Yogyakarta: Penerbit Andi.

Winarno, W.W. 2011. Analisis Ekonometrika dan Statistika dengan Eviews Ed. Ketiga. Yogyakarta: Unit Penerbit dan Percetakan STIM YKPN.

Wijaya, Tony. 2009. Analisis Data Menggunakan SPSS. Yogyakarta: Universitas AtmaJaya Yogyakarta. 